As Launer explains when managing each consultation it 'goes far beyond so-called 'patient-centred' medicine. It means recognising the equal legitimacy of the patient's need for self-expression and one's own need as a doctor to achieve pattern recognition, action and closure. ${ }^{10}$

Both patient and doctor need to go around their circle of understanding. Acknowledging these two circles of understanding in conversation could help the doctor to appreciate the skill of using careful listening, questioning and imaginative ideas to alter a patient's horizon. A skill which I feel is the very essence of general practice.

I offer these ideas as a way to appreciate what is happening when we have a dialogue with a patient. Helping the patient to 'finetune' their understanding is crucial in a good consultation as this enables them to change their horizon. For the doctor there may be other benefits. Gadamer says that 'the real power of hermeneutical consciousness is our ability to see what is questionable'. ${ }^{6}$ It enables us to join our experience of science to our own universal and human experience of life. It is during this process that I also believe the doctor gains wisdom.

\section{Jeff Clark}

\section{REFERENCES}

1. Pendleton D, Schofield T, Tate P, Havelock P. The consultation: an approach to learning and teaching. Oxford: Open University Press, 1984.

2. Campion P, Foulkes J, Neighbour R, Tate P. Patient centredness in the MRCGP video examination: analysis of large cohort. BMJ 2002; 325: 691-692.

3. Gadamer H-G. Truth and method. 2nd revised edn. London: Continuum International Publishing Group, 2004.

4. Gadamer H-G. On the scope and function of hermeneutical reflection (1967). In: Linge DF Philosophical hermeneutics. Berkeley, CA: University of California Press, 1977: 18-43.

5. Turner, d S. Horizons revealed: From methodology to method. International Journal of Qualitative Methods 2003, 2(1): Article 1. http://www.ualberta.ca/ iiqm/ backissues/2_1/html/turner.html (accessed 27 Nov 2007).

6. Gadamer H-G. The universality of the hermeneutical problem (1966). In: Linge DE. Philosophical hermeneutics. Berkeley, CA: University of California Press, 1977: 3-17.

7. Wittgenstein L. Tractatus Logico-Philosophicus. London: Kegan Paul, Trench, Trubner, 1922.

8. Linge DE. Philosophical hermeneutics. Berkeley, CA: University of California Press, 1977.

9. Launer J. Narrative-based primary care: a practical guide. Abingdon: Radcliffe, 2002.

10. Launer J. Uniqueness and conformity. Q J Med 2003; 96: 615-616.

DOI: 10.3399/bjgp08X263929

\title{
Salaried doctors: the problems
}

In general practice differing groups face different problems. The relative professional isolation of salaried GPs employed by practices leaves them vulnerable to exploitation and support mechanisms for them are often 'ad hoc' or non-existent. Satisfaction in a salaried post is associated with a robust and fair contract, interest from employers in the skills and attributes of the GP, and a commitment to career development. In some situations these are lacking for the salaried GP, leading to de-motivation and a search for employment in other areas of the health service. In my work as an appraiser, trainer, and GP for 30 years I have increasingly recognised this as a problem.

One salaried GP described to me her low self-esteem and loss of selfconfidence following years in a practice where she rarely met the partners and was never asked to practice meetings. Another felt overwhelmed by the demands of patients who preferred her to the other partners. As a conscientious, caring, and careful GP, inevitably her surgeries would overrun and this was compounded by 'hot bedding', which often meant that she could not gain access to a consulting room in time to start her surgery. With childcare arrangements and school collecting times she was always stressed and pulled in different directions. Attempts to modify her contract fell on deaf ears and now she is considering a career outside general practice.

Other GPs have equally harrowing tales. Another of bullying by partners in a practice where one partner sat with his door open listening to her surgeries and interrogating any of her patients on leaving to see if they were 'upset'. As a caring doctor, her consultation rate for depression was high and of course many patients were distressed. However, they were very appreciative of her skills. She was able to confront the partner's behaviour but at great cost to her selfesteem and confidence.
A practice told another GP who had worked conscientiously for 2 years that his services were no longer required with no explanation and with 1 month's notice. $\mathrm{He}$ had never had an appraisal in the practice and no partner had ever told him of any problems. He was informed of the termination of his employment by the practice manager.

Logistics are another hurdle in the life of a salaried doctor. If they move around several practices no room is the same. They often resort to carrying their own equipment and forms as it saves time. Local protocols and clinical pathways might pass them by as they are out of the information loop.

Safeguarding good doctors from exploitation is imperative if general practice is to continue to fulfil the needs of the future. Whatever we may feel about salaried practice, it is undoubtedly here to stay. A salaried GP costs a practice $£ 7000$ to replace and makes retention a priority. It is time to listen to the voices from this group and give them the recognition they deserve.

\section{Julia Lecky}

\section{FURTHER READING}

Aquino P, Kohli B. Salaried general practitioners. BMJ Career Focus 2002; 325: S89a

BMA Salaried GP Contracts: http://www.bma.org.uk/ap.nsf/Content/Hubsalariedgps

DOI: 10.3399/bjgp08X263938 